\title{
Differential proteomic profiling of endometrium and plasma indicate the importance of hydrolysis in bovine endometritis
}

\author{
Shi-Dong Zhang, ${ }^{*} \dagger$ Shu-Wei Dong, † Dong-Sheng Wang,† Chike F. Oguejiofor, $\ddagger$ Ali A. Fouladi-Nashta,§ \\ Zhi-Qiang Yang, ${ }^{*} \dagger^{1}$ and Zuo-Ting Yan* ${ }^{1}$ \\ *Lanzhou Institute of Husbandry and Pharmaceutical Sciences of Chinese Academy of Agricultural Sciences, Lanzhou 730050, China \\ †Key Laboratory of Veterinary Pharmaceutics Discovery, Ministry of Agriculture, Lanzhou 730050, China \\ †Department of Veterinary Obstetrics and Reproductive Diseases, University of Nigeria, Nsukka 410001, Nigeria \\ §Reproduction Group, Royal Veterinary College, Hawkshead Campus, Hatfield AL97TA, United Kingdom
}

\begin{abstract}
Endometritis is an important disease of dairy cows that leads to significant economic losses in the dairy cattle industry. To investigate the alteration of proteins associated with endometritis in the dairy cow, the isobaric tags for relative and absolute quantification (iTRAQ) technique was applied to quantitatively identify differentially expressed proteins (DEP) in the endometrium and peripheral plasma of Chinese Holstein cows with endometritis. Compared with the normal (control) group, $159 \mathrm{DEP}$ in the endometrium and 137 DEP in the plasma were identified in cows with endometritis. Gene ontology analysis demonstrated that the predominant endometrial DEP were primarily involved in responses to stimulus and stress processes and mainly played a role in hydrolysis in the extracellular region. The predominant plasma DEP were mainly components of the cytosol and non-membrane-bound organelles, and they were involved in the response to stress and regulation of enzyme activity. Protein-protein interaction of tissue DEP revealed that some core seed proteins, such as RAC2, ITGB2, and CDH1 in the same network as CD14, MMP3, and MMP9, had important functions in the cross-talk of pathways related to extracellular proteolysis. In summary, significant enzymatic hydrolase activity in the extracellular region is proposed as a molecular mechanism by which altered proteins may promote inflammation and hence endometritis.
\end{abstract}

Key words: isobaric tags for relative and absolute quantification (iTRAQ), bovine endometritis, differentially expressed proteins, hydrolysis

\footnotetext{
Received November 27, 2016.

Accepted May 29, 2017.

${ }^{1}$ Corresponding authors: zhiqyang2006@163.com and yanzuoting@ caas.cn
}

\section{INTRODUCTION}

Uterine infection and endometritis are important causes of infertility and reproductive losses in dairy cattle worldwide (Gilbert, 2011; LeBlanc, 2014). The protective physical barriers to contamination provided by the uterine luminal epithelium, cervix, vagina, and vulva are all disrupted during normal parturition (Sheldon and Dobson, 2004). This disruption and the large volumes of fluid and tissue debris in the uterine lumen both allow bacteria from the environment or the animal's feces to contaminate the uterus postpartum (Bondurant, 1999; Sheldon and Dobson, 2004). Several studies showed the presence of bacteria in the uterus of more than $90 \%$ of cows within the first 2 wk after calving (Dohmen et al., 1995; Sheldon et al., 2008). Although most bacterial contaminants are gradually cleared from the uterus via uterine involution and innate immune response (Azawi, 2008; Singh et al., 2008), up to $20 \%$ of cows have clinical metritis and $20 \%$ to over $50 \%$ of cows subsequently develop subclinical inflammation of the uterus (endometritis) beyond $3 \mathrm{wk}$ postpartum (Sheldon et al., 2009a; LeBlanc, 2014). Endometritis causes uterine tissue damage, embryonic death and early abortion, delayed onset of ovarian cyclicity, extended luteal phases, and reduced conception rates in affected cattle (Sheldon et al., 2009b; Gilbert, 2011). These problems lead to infertility and substantial financial losses in the dairy industry (Sheldon et al., 2009a).

The endometrium has crucial roles in female reproduction including the regulation of the estrous cycle, sperm transit, nourishment of the early embryo, and formation of the placenta. Furthermore, the endometrial luminal epithelial cells and the underlying stromal cells express pathogen recognition receptors and mount an innate immune response to microbes or microbial ligands (Hickey et al., 2011; Oguejiofor et al., 2015a,b). The major bacteria isolated from cows with endometritis include Escherichia coli and Trueperella pyogenes, followed by other anaerobic species, such as Fusobacte- 
rium and Bacteroides (Dohmen et al., 2000; Williams et al., 2005; Bicalho et al., 2012). Although the effects of different types of bacteria on uterine disease mechanisms are not completely understood (Westermann et al., 2010), unregulated inflammation is known to lead to disease (Maybin et al., 2011). This outcome can impair reproductive performance not only during the infection but also after the clinical signs of endometritis have resolved (Plöntzke et al., 2010; LeBlanc, 2014). Interestingly, some evidence suggests that certain viruses such as bovine viral diarrhea virus (Grooms, 2004; Oguejiofor et al., 2015a; Cheng et al., 2016) and bovine herpes virus-4 (Donofrio et al., 2009) contribute to the etiology of uterine disease.

Endometritis is described histopathologically as a superficial inflammation of the endometrium, with histological evidence of inflammation (Sheldon et al., 2006). Endometritis has been defined based on the presence of abnormally increased PMN in uterine luminal fluid (Kasimanickam et al., 2004; Gilbert et al., 2005) or the biopsy of endometrial tissue (Galvão et al., 2011). In addition, increased endometrial expression of inflammatory genes may be present, including genes coding for granulocyte chemotactic protein 2, IL-1 $\beta$ and IL-8, and tumor necrosis factor (TNF) (Fischer et al., 2010; Kasimanickam et al., 2014). Elevated levels of inflammatory cytokines (TNF- $\alpha$, IL-1 $\beta$, IL-6, IL-10) in serum have also been used to identify the development of bovine endometritis (Islam et al., 2013; Kasimanickam et al., 2013). Previously, genome-wide transcriptomic profiling of bovine endometrium using mRNA-Seq showed that immune activation and inflammation preceded tissue proliferation and repair in the healthy postpartum endometrium (Foley et al., 2012). This finding highlighted the importance of a balanced inflammatory immune response as key to sufficient bacterial clearance and restoration of an endometrial environment capable of supporting a new pregnancy (Jabbour et al., 2009). Limited studies exist on the bovine uterine proteome. One study identified 9 proteins using 2-dimensional (2D) electrophoresis to compare the proteins present in the uterine luminal fluid between pregnant and nonpregnant animals (Ledgard et al., 2009). Another study used 2D fluorescence difference in-gel electrophoresis to compare the proteome of the pregnant and nonpregnant endometrium (Berendt et al., 2005). However, scant information is available on the proteomic profile of cows with endometritis. A previous study identified 14 endometritis-associated proteins using 2D electrophoresis (Choe et al., 2010).

Recent developments in the field of proteomics have led to a renewed interest in animal disease diagnosis and treatment. Isobaric tags for relative and absolute quantification (iTRAQ) is the most popular technique, and combined with multidimensional liquid chromatography (LC) and tandem MS, it is used to study differentially expressed proteins (DEP). The aim of this study was to use the iTRAQ technique to characterize the proteomic changes in endometrial tissue and plasma from Chinese Holstein dairy cows with endometritis. The bioinformatics analysis of the differential proteome may enable a new understanding of the main proteins or pathways associated with bovine endometritis and provide a foundation for future diagnosis and treatment of diseased animals.

\section{MATERIALS AND METHODS}

\section{Animals and Collection of Samples}

Sample collection was carried out under license in accordance with national guidelines (Ministry of Agriculture of China 2015/No. 18). Rectal palpation and cervico-vaginal mucus observation were conducted to identify normal animals or cows with endometritis. Endometrial biopsies and blood specimens were collected from Chinese Holstein cows, aged from 2 to 5 yr, at 21 to 35 d postpartum. Ten candidate cows had obvious signs of clinical endometritis (i.e., presence of purulent or mucopurulent vaginal discharge), but they did not show any symptoms of other local or systemic diseases beyond the focus of this study. Another 10 cows without signs of endometritis were categorized as the normal control animals. Briefly, $5 \mathrm{~mL}$ of blood was collected from the jugular vein into commercial vacuum tubes and thoroughly mixed with the anticoagulant EDTA $\mathrm{K}_{2}$. This samples were centrifuged at 2,500 $\times$ $g$ for $15 \mathrm{~min}$, and $0.5 \mathrm{~mL}$ of plasma was recovered and quickly frozen with liquid nitrogen. Endometrial biopsies were quickly frozen in liquid nitrogen and fixed in $4 \%$ formalin, respectively. After formalin fixation, tissue specimens were embedded in paraffin blocks using routine procedures, followed by hematoxylin and eosin staining and histopathological examination under the microscope to identify pathological state.

\section{Protein Isolation, Digestion, and Labeling with ITRAQ Reagent}

Protein extraction was performed on 4 nonendometritis samples and 4 endometritis samples that were selected according to histopathological results. Briefly, the frozen tissue was ground into powder and then dissolved in lysis buffer I ( $7 M$ urea, $2 M$ thiourea, $4 \%$ propanesulfonic acid, $40 \mathrm{~m} M$ Tris- $\mathrm{HCl}, \mathrm{pH} 8.5$ ) containing complete protease inhibitor. The cells were lysed by 
sonication at $200 \mathrm{~W}$ for $15 \mathrm{~min}$ and then centrifuged at $4^{\circ} \mathrm{C}, 30,000 \times g$ for $15 \mathrm{~min}$. The supernatant was mixed with $5 \times$ volume of chilled acetone containing $10 \%$ (vol/ vol) trichloroacetic acid, incubated at $-20^{\circ} \mathrm{C}$ overnight, and then centrifuged as described. The precipitate was washed 3 times in chilled acetone. The recovered pellet was air-dried and dissolved in lysis buffer II ( $7 M$ urea, $2 M$ thiourea, $4 \%$ Nonidet P40, $20 \mathrm{~m} M$ Tris- $\mathrm{HCl}$, $\mathrm{pH}$ 8.0-8.5). The suspension was sonicated, centrifuged as described, and transferred to another tube. The disulfide bonds were reduced by treatment with $10 \mathrm{~m} M$ dithiothreitol, whereas cysteines were blocked by treatment with $55 \mathrm{~m} M$ iodoacetamide. The supernatant was then washed in acetone and centrifuged as previously described. Recovered pellets were air-dried, dissolved in $500 \mu \mathrm{L}$ of $0.5 \mathrm{M}$ tetraethylammonium bromide (TEAB; Applied Biosystems, Milan, Italy), and sonicated once more. Finally, samples were centrifuged, and the supernatant was transferred to a new tube and quantified using the Bradford method. The proteins in the supernatant were kept at $-80^{\circ} \mathrm{C}$ for further analysis. Correspondingly, the plasma samples (matching the endometrial tissues) were cleared of highly abundant proteins using ProteoMiner kit (Bio-Rad, Hercules, $\mathrm{CA}$ ), and other processes, including washing, precipitation, centrifugation, sonication, and the reduction of disulfide bonds, were performed as already described.

Total protein $(100 \mu \mathrm{g})$ was measured from each sample solution and the protein was digested at $37^{\circ} \mathrm{C}$ for $16 \mathrm{~h}$ with Trypsin Gold (Promega, Madison, WI) with a protein-to-trypsin ratio of 30:1. After trypsin digestion, peptides were dried by vacuum centrifugation. Peptides were reconstituted in $0.5 \mathrm{M}$ TEAB and processed according to the manufacture's protocol for 8-plex iTRAQ reagent (Applied Biosystems). Briefly, 1 unit of iTRAQ reagent was thawed and reconstituted in $24 \mu \mathrm{L}$ of isopropanol. Samples were labeled respectively with different isobaric tags and incubated at room temperature for $2 \mathrm{~h}$. The labeled peptide mixtures were then pooled and dried by vacuum centrifugation.

\section{Liquid Chromatography-Electrospray lonization Tandem Mass Spectrometry Analysis Based on $Q$ Exactive}

The iTRAQ-labeled peptide mixtures were fractionated by strong cation exchange chromatography, which was conducted on a LC-20AB HPLC Pump system (Shimadzu, Kyoto, Japan) using a $4.6 \times 250 \mathrm{~mm}$ Ultremex SCX column containing $5-\mu \mathrm{m}$ particles (Phenomenex, Torrance, CA). The peptides were eluted at a flow rate of $1 \mathrm{~mL} / \mathrm{min}$ with a gradient of buffers as follows: buffer A $\left[25 \mathrm{mM} \mathrm{NaH}{ }_{2} \mathrm{PO}_{4}\right.$ in $25 \%$ acetonitrile
(ACN), pH 2.7] for $10 \mathrm{~min}, 5$ to $60 \%$ buffer B (25 mM $\mathrm{NaH}_{2} \mathrm{PO}_{4}, 1 \mathrm{M} \mathrm{KCl}$ in $25 \% \mathrm{ACN}, \mathrm{pH} 2.7$ ) for $27 \mathrm{~min}$, and 60 to $100 \%$ buffer B for 1 min. The system was then maintained at $100 \%$ buffer B for 1 min before equilibrating with buffer A for 10 min before the next injection. Under a monitoring absorbance of $214 \mathrm{~nm}, 20$ fractions were collected, desalted with a Strata X C18 column (Phenomenex), and vacuum-dried.

Each fraction was dissolved in buffer liquid $(2 \% \mathrm{ACN}$, $0.1 \%$ formic acid) and centrifuged at 20,000 $\times g$ for 10 min; the final concentration of peptide was about 0.5 $\mu \mathrm{g} / \mu \mathrm{L}$ on average. Ten microliters of supernatant was loaded on a LC-20AD nanoHPLC (Shimadzu, Kyoto, Japan) by the autosampler onto a 2-cm C18 trap column (i.d. $75 \mu \mathrm{m}$ ). The peptides were subjected to nanoelectrospray ionization followed by tandem mass spectrometry (MS/MS) in a Q Exactive (Thermo Fisher Scientific, San Jose, CA) coupled online to the HPLC. Intact peptides were detected in the Q Exactive orbitrap at a resolution of 70,000. Peptides were selected for MS/MS using high-energy collision dissociation operating mode with a normalized collision energy setting of 27.0; ion fragments were detected in the Orbitrap at a resolution of 17,500. A data-dependent procedure that alternated between $1 \mathrm{MS}$ scan followed by $15 \mathrm{MS}$ / MS scans was applied for the 15 most abundant precursor ions above a threshold ion count of 20,000 in the MS survey scan with a following a dynamic exclusion duration of $15 \mathrm{~s}$. The electrospray voltage applied was $1.6 \mathrm{kV}$. Automatic gain control was used to optimize the spectra generated by the orbitrap. The automatic gain control target for full MS and MS2 was 3E6 ion counts and 1E5 ion counts, respectively. The $m / z$ scan range was 350 to 2,000 Da. For MS2 scans, the $\mathrm{m} / z$ scan range was 100 to 1,800 Da.

\section{Data Analysis}

Raw MS data were converted into Mascot generic file (MGF) using Proteome Discoverer 1.2 (PD 1.2, Thermo Fisher Scientific), and the MGF data file were searched by using Mascot search engine (version 2.3.02, Matrix Science, London, UK) to identify proteins. Each confident protein identification involved at least 1 unique peptide. For protein quantification, a protein had to contain at least 2 unique spectra. The quantitative protein ratios were weighted and normalized by the median ratio in Mascot (http://www.matrixscience .com/help/quant_statistics_help.html). We only used ratios with $P$-values $<0.05$, and we set fold changes of $>1.5$ or $<0.67$ for endometrial tissue and $>1.2$ or $<0.67$ for plasma as the criteria to determine up- or down-regulated proteins, respectively. 


\section{Bioinformatics Analyses}

Functional annotations of proteins were performed using Blast2GO program against the nonredundant protein database (NR, NCBI; http://www.ncbi.nlm .nih.gov/protein/?term=txid9913[Organism:noexp]). Gene Ontology (GO) is an international standardization of gene function classification system. It has 3 ontologies that can describe molecular function, cellular component, and biological processes, respectively. The main types of annotations were obtained from the GO consortium website (http://david.abcc.ncifcrf.gov/ ). A Venn diagram was drawn using online Venny 2.0 (http://bioinfogp.cnb.csic.es/tools/venny/index.html). The protein-protein interaction (PPI) network was analyzed using STRING (Search Tool for the Retrieval of Interacting Genes/Proteins) software (http://string .embl-heidelberg.de/). The DEP were compared by a hierarchial cluster analysis using Cluster 3.0 (http:// bonsai.hgc.jp/ mdehoon/software/cluster/software .htm). The data were displayed using Tree View software (https://sourceforge.net/projects/jtreeview/).

\section{Western Blot}

The same endometrial tissues that were used for iTRAQ analysis were divided into nonendometritis and endometritis groups. Total proteins were extracted from each sample using a commercial kit (BestBiotech, Shanghai, China). Protein concentration was determined using the BCA Protein Assay Kit (Biomiga, Shanghai, China). Briefly, equivalent amounts of protein $(20 \mu \mathrm{g})$ were loaded on $12 \%$ SDS-PAGE gels and then transferred onto $0.45-\mu \mathrm{m}$ nitrocellulose membrane (Millipore Corp., Billerica, MA). After blotting, the membrane was blocked with 5\% skim milk and incubated with primary antibody and second antibody at $37^{\circ} \mathrm{C}$ for $60 \mathrm{~min}$, respectively. The incubated membrane was then washed in $0.05 \%$ PBS Tween 3 times. Detection was performed using chemiluminescence luminol reagents (CWbiotech, Beijing, China) and recorded by film exposure. The polyclonal antibodies to serum amyloid A (sc-20275), myeloperoxidase (sc-16128-R), matrix metalloproteinase 3 (sc-6839), fibrinogen (sc33916), integrin $\beta 6$ (sc-6632), and integrin $\beta 2$ (sc-6623) were purchased from Santa Cruz Biotechnology (Santa Cruz, CA). Mouse monoclonal antibody to $\beta$ actin (ab8226) and goat polyclonal antibody to lactoferrin (ab112968) were obtained from Abcam (Cambridge, UK). The horseradish peroxidase-conjugated goat anti-mouse IgG and rabbit anti-goat IgG were obtained from Proteintech (Wuhan, China).

\section{RESULTS}

\section{Histopathology of Endometrial Tissue}

A representative section showing typical histopathologic changes observed in the endometrial tissue specimens from cows with endometritis are shown in Figure 1. The normal endometrium comprises a single layer of columnar luminal epithelial cells. The endometrial gland lies deeper in the stromal layer and comprises the glandular epithelia, which release their secretions into the lumen of the gland. The lamina propria contained few red blood cells or migrant granulocytes and lymphocytes (Figure 1A). During inflammation in the uterus or endometritis (Figure 1B), degenerative necrosis was apparent in the luminal epithelial cells, with nuclear condensation and damage of the mucous layer and basement membrane. Capillaries were expanded in the lamina propria, with significant infiltration of red blood cells and leukocytes, resulting in a general increase in cell density. This pattern was typical of hemorrhagic endometritis (Figure 1B).

\section{Protein Profile by iTRAQ-Coupled 2D LC-MS/MS Analysis}

A total of 3,493 proteins were determined by iTRAQcoupled 2D LC-MS/MS analysis in the endometrial tissue. Among them, 159 proteins displayed significantly altered levels with fold cut-off of $\geq 1.5$. As shown in Supplemental Table S1 (https://doi.org/10.3168/jds .2016-12365), these significantly altered proteins include 109 increased and 50 decreased ones. Analysis of the plasma identified $137 \mathrm{DEP}$ with fold cut-off of $\geq 1.2$, out of which 49 proteins were increased and 88 were decreased (Supplemental Table S1).

\section{Functional Classifications of DEP}

Functional annotation of the DEP was initially performed using Blast2GO program. Three main types of annotations were obtained from the GO consortium website: cellular component, metabolic functions, and biological processes. One hundred fifty-nine proteins were significantly altered in the endometritic uterus, and enrichment analysis of biological processes showed that endometritis primarily affected response to stimulus and stress (Figure 2A). Enrichment analysis also identified hydrolase activity as a predominant event for stress and stimulus during inflammation (Figure 2C). Furthermore, cellular component-based enrichment analysis identified the significantly altered proteins as being located in the extracellular region (Figure 2B). 
The same GO analysis was conducted on 137 proteins identified in the plasma. Biological processes associated with DEP mainly involved in stress response (Figure $3 \mathrm{~A}$ ) and molecular function regulation of enzyme activities (Figure 3C). Some plasma DEP were involved in components of non-membrane-bound organelle and cytoskeletal processes (Figure 2B), such as PDZ and LIM domain 2 (PDLI2), coronin-1A (COR1A), annexin A1 (ANXA1), and ribosomal protein L14 (RL14; Supplemental Table S2; https://doi.org/10 $.3168 /$ jds.2016-12365).

\section{Protein Distribution Between Endometrium and Plasma}

The endometrial tissue contained 159 DEP, and the plasma had 137 DEP. However, only 9 proteins occurred in both the endometrial tissue and plasma. Of these proteins, 3 were similarly increased and 2 were similarly decreased in the 2 specimens; 3 proteins were increased in the tissue, but decreased in the plasma; and 1 was increased in the plasma, but decreased in the tissue. The distribution of these proteins is shown in a Venn diagram (Figure 4). Cluster analysis was performed for the 9 proteins as shown in the dendrogram (Figure 4). These include hemoglobin subunit $\beta$ (HBB), resistin (RETN), serum amyloid A protein (SAA), inter- $\alpha$-trypsin inhibitor heavy-chain $\mathrm{H} 2$ precursor, IgA heavy-chain constant region, immunoglobulin gamma 1 heavy-chain constant region, CD14, matrix metallo- proteinase 3 (MMP3), and serpin peptidase inhibitor, clade A ( $\alpha-1$ antiproteinase, antitrypsin), member 10.

\section{Validation of Changes in Protein Level by Western Blot}

To validate the DEP identified by the iTRAQ analysis, 7 increased proteins were selected for Western blot analysis, including SAA, lactoferrin, myeloperoxidase, MMP3, fibrinogen, integrin $\beta 6$, and integrin $\beta 2$. Equal amounts of proteins from endometrial tissue were detected with antibodies as shown in Figure 5. The results showed that the ratios of the selective proteins were consistent with those obtained from the iTRAQ analysis.

\section{Analysis of Protein-Protein Interaction}

The interactions between proteins are complex and interrelated during disease development. Studying the interaction network is of strategic importance to researchers for understanding how disease-related proteins interact with each other and how they affect cell function. To investigate these issues, the STRING database was searched for protein interactions with the 159 DEP in endometrial tissue (Figure 6). As observed from the network, RAC2, ITGB2, and CDH1 were the core seed proteins in the interaction network, and they had important functions in several signal transduction pathways including MAPK signaling pathway, VEGF
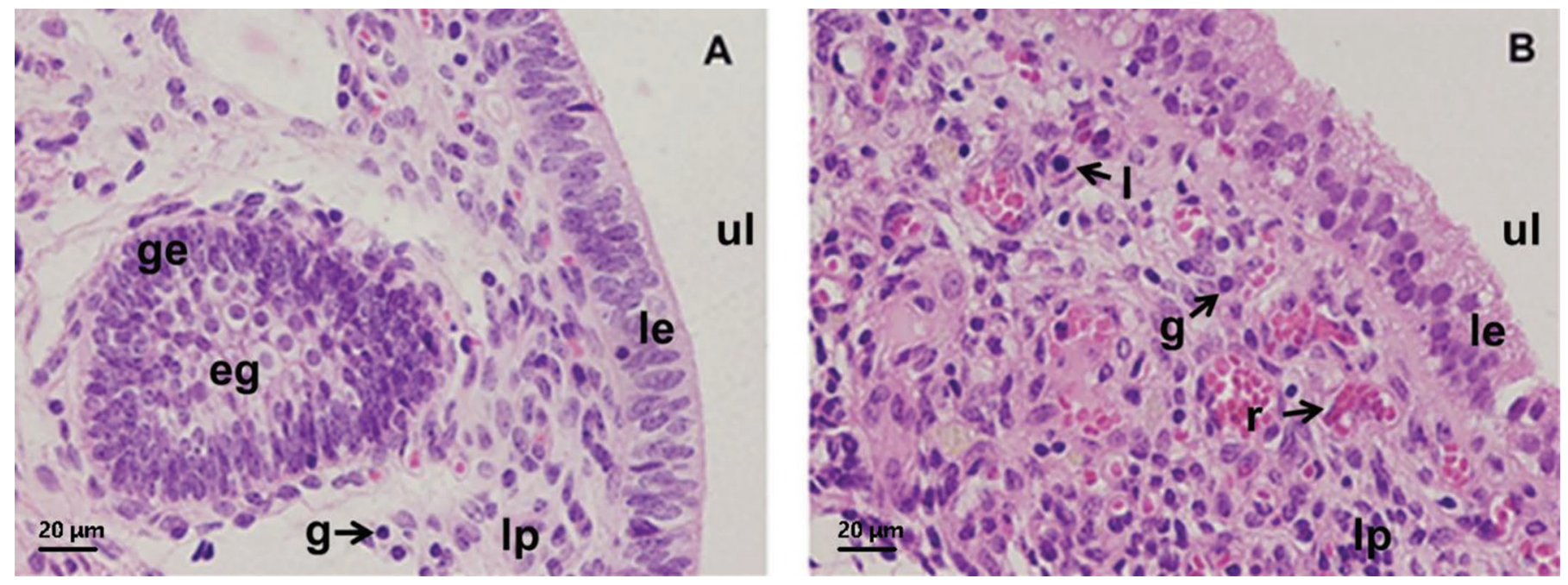

Figure 1. Histopathologic change in endometrial tissue without endometritis (A) and with endometritis (B) investigated following hematoxylin and eosin staining $(400 \times)$. Micrographs of the bovine endometrium showing normal tissue (A) and histopathologic changes observed during endometritis (B). $\mathrm{ul}=$ uterine lumen; $\mathrm{eg}=$ endometrial gland; le = luminal epithelium; ge = glandular epithelium; lp $=$ lamina propria; $\mathrm{g}=$ granulocytes; $\mathrm{l}=$ lymphocytes; $\mathrm{r}=$ red blood cells. 
signaling pathway, Wnt signaling pathway, focal adhesion, adherens junction, cell adhesion molecules, leukocyte transendothelial migration, and regulation of actin cytoskeleton.

\section{DISCUSSION}

Endometritis is prevalent in dairy herds worldwide, causing significant economic losses resulting from infertility (Sheldon et al., 2009a). Nevertheless, research on endometritis in dairy cows is limited by high costs, a long gestation period, and lack of uniform genetic backgrounds. With the development of omics research, proteomics is emerging as a useful tool for studying endometritis in cows. Understanding the molecular mechanisms of endometritis at the protein level is likely to contribute to the design of new methods in disease control and fertility enhancement.

Diagnosis of endometritis in cows is based on the presence of pathologic vaginal discharge. In the past $10 \mathrm{yr}$, standardized definitions and characterizations of uterine disease were suggested by several authors (Williams et al., 2005; Barlund et al., 2008; LeBlanc et al., 2011). Different physiological conditions well understood to possibly influence a cow's endometrium include DIM, estrus cycle, and age. However, correcting for all

A
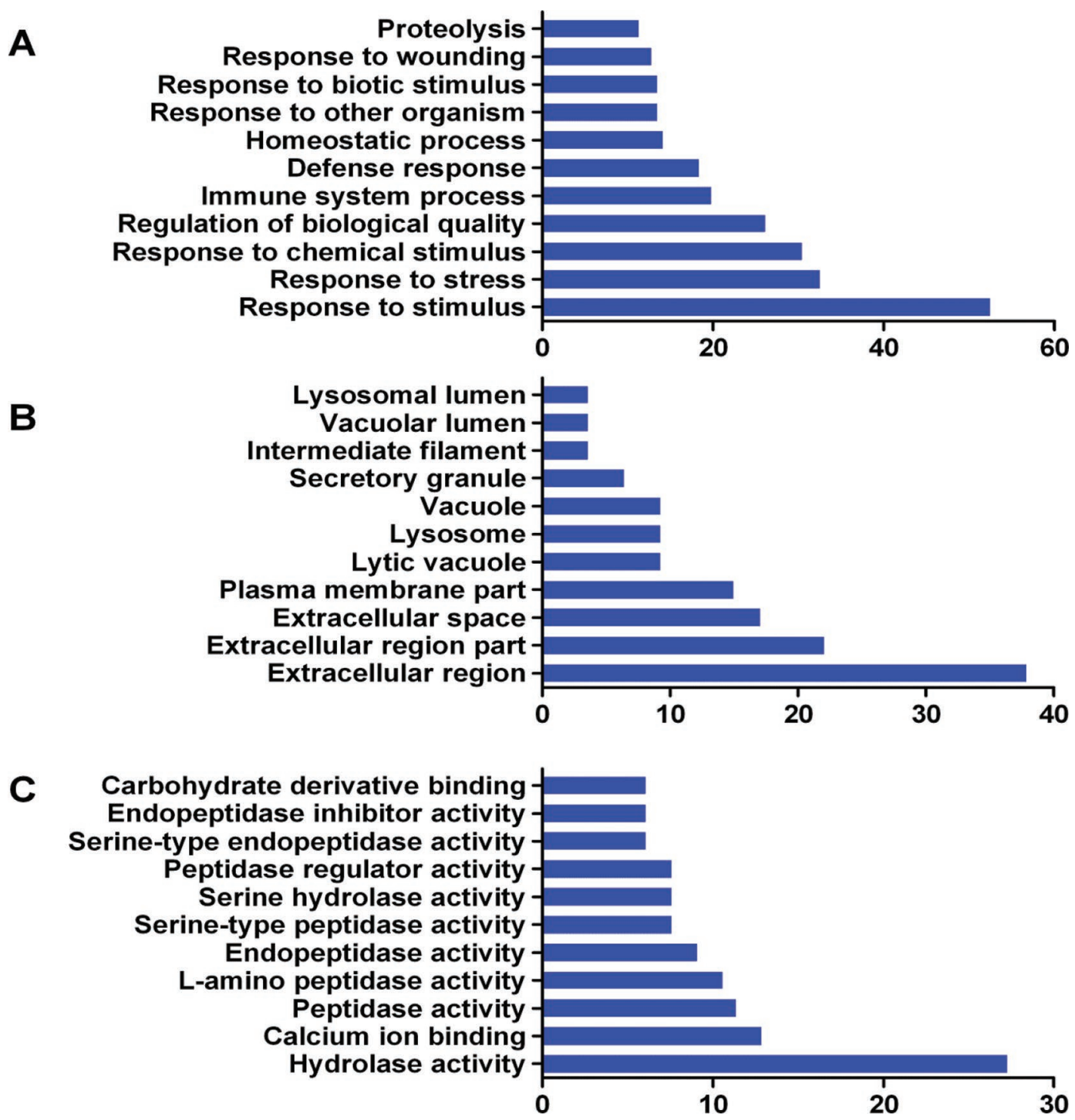

Figure 2. Top 11 classifications of identified proteins differentially expressed in the endometrium based on their functional annotations using the Gene Ontology enrichment analysis: (A) biological processes, (B) cellular components, and (C) molecular functions. Color version available online. 


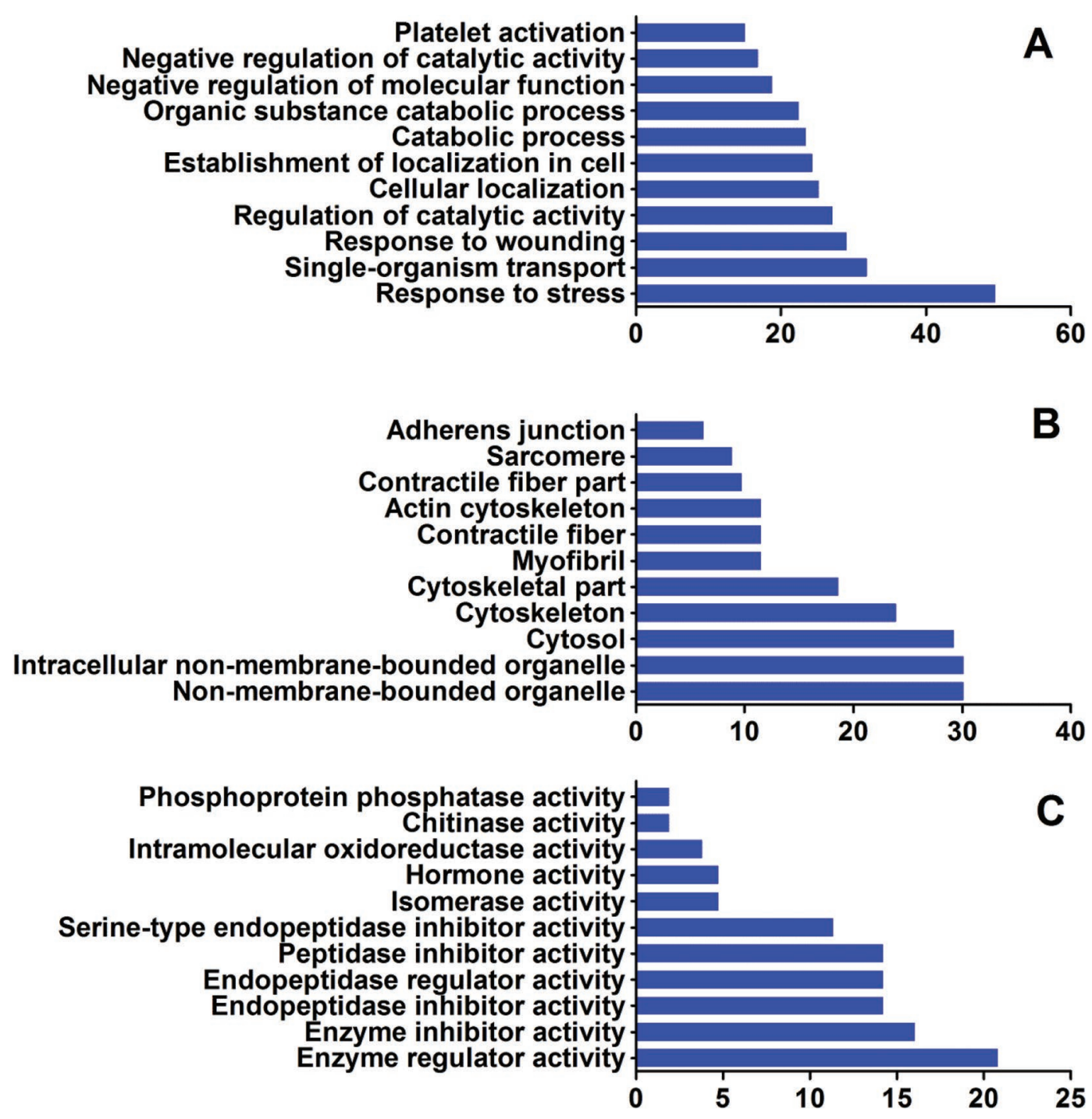

Figure 3. Top 11 classifications of the identified proteins differentially occurring in plasma based on their functional annotations using the Gene Ontology enrichment analysis: (A) biological processes, (B) cellular components, and (C) molecular functions. Color version available online.

variables is difficult when working with farm animals such as cattle as opposed to working with controlled laboratory animals and conditions. We were unable to determine the exact days of the estrous cycle and DIM of the animals, and therefore we cannot account for any influence due to ovarian hormones. In the absence of the accurate information of cow's physiology, we herein conducted histopathologic study using hematoxylin and eosin staining to characterize endometritis (Figure 1 ), and only tissues with the same type of hemorrhagic endometritis were selected for proteomic analysis.

According to the results of iTRAQ analysis, approximately 3,500 bovine proteins were identified, and with a $P$-value cut-off of $<0.05,159$ and 137 proteins were found to expressed differentially in the endometrial tissue and plasma, respectively (Supplemental Tables S1 and S2; https://doi.org/10.3168/jds.2016-12365). As shown in Supplemental Table S1, DEP in the endometrial tissue of cows with endometritis included many specific and nonspecific immunity-associated proteins, providing evidence of on-going inflammatory activity. Five cathelicidin proteins (cathelicidins 2, 3, 5, 6, and 7), a family of host-defense peptides, were significantly increased. These small amphipathic peptides exhibit rapid and potent activity against many pathogens, including bacteria, viruses, and fungi (Braff et al., 2005).

The complement proteins, complement component $1, \mathrm{r}$ subcomponent $(\mathrm{C} 1 \mathrm{R})$ and complement component 
A

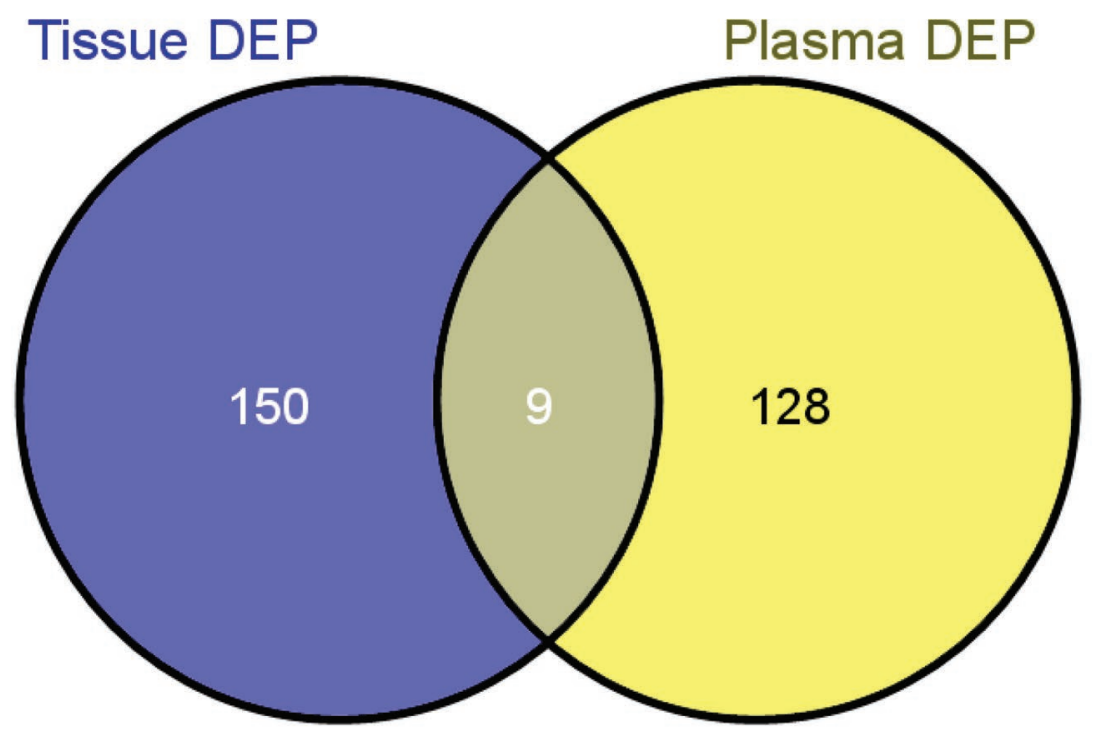

B

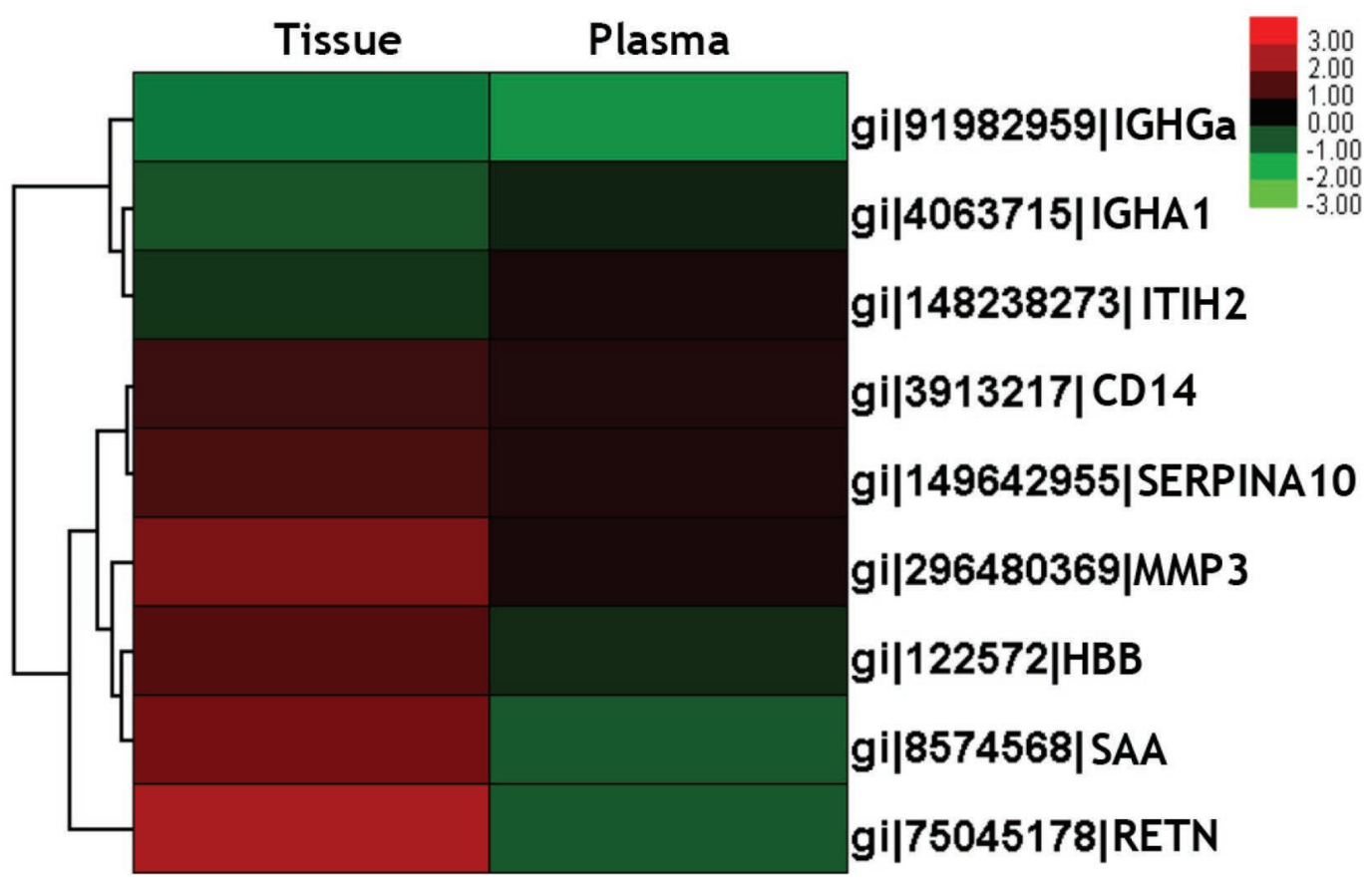

Figure 4. Venn diagram showing the distribution of proteins between endometrial tissue and plasma (A), and cluster analysis of 9 shared differentially expressed proteins (DEP) in tissue and plasma (B). IGHGa = immunoglobulin gamma 1 heavy chain constant region; IGHA1 = IgA heavy chain constant region; ITIH2 = inter- $\alpha$-trypsin inhibitor heavy chain H2 precursor; CD14 = cluster of differentiation 14; SERPINA10 = serpin peptidase inhibitor, clade A (alpha-1 antiproteinase, antitrypsin), member 10; MMP3 = matrix metalloproteinase 3; HBB = hemoglobin subunit $\beta$; SAA = serum amyloid A protein; RETN = resistin. Color version available online. 


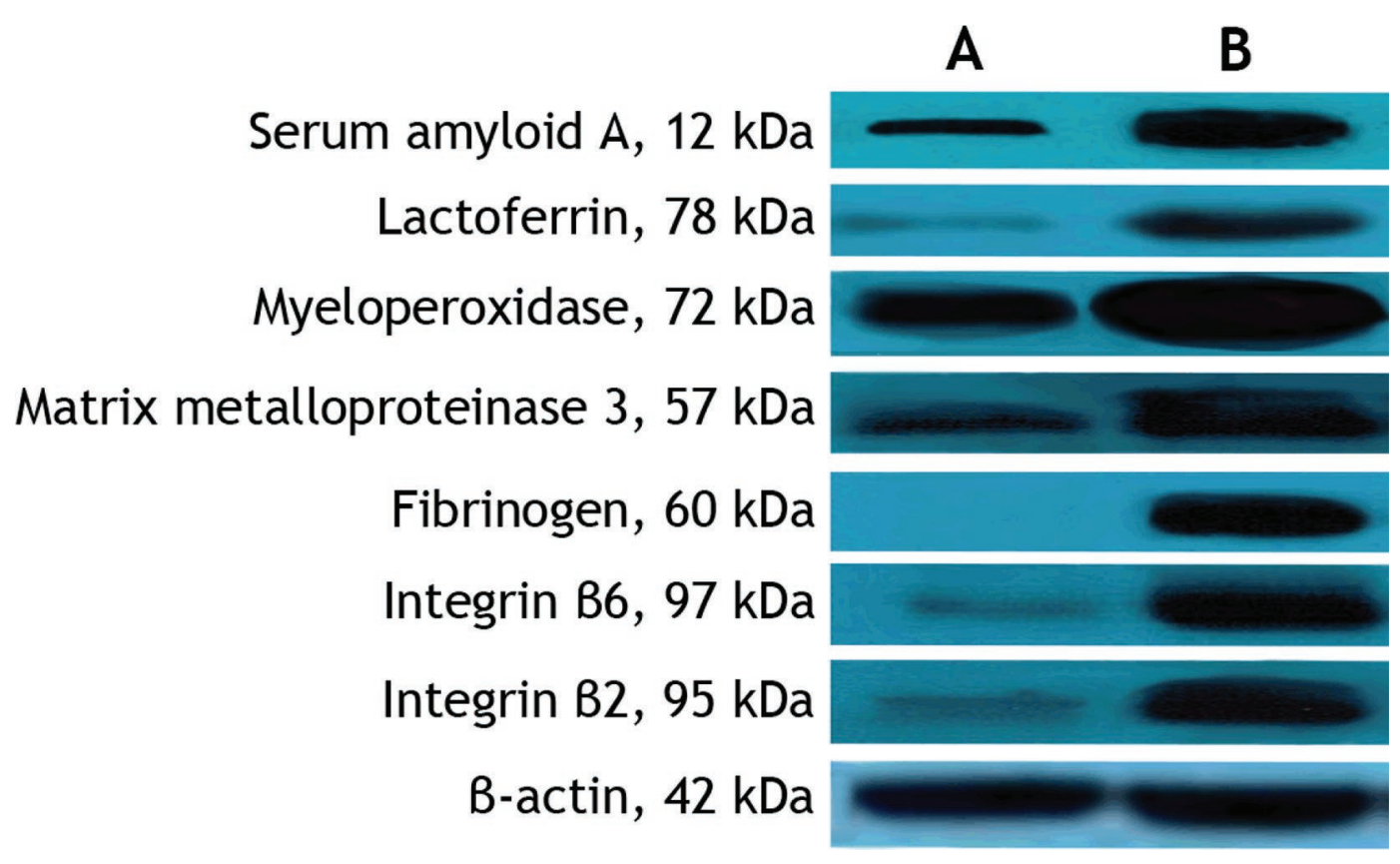

Figure 5. Confirmation of 7 differentially expressed proteins by Western blot analysis in (A) the nonendometritis group, and (B) the endometritis group. $\beta$-Actin was used as an internal reference to normalize the quantitative data. The figure is a representative result, which was tested in each animal one time, with a similar result in 4 samples. Color version available online.

1, s subcomponent $(\mathrm{C} 1 \mathrm{~S})$, were also increased in the endometrium. Complement proteins are important in innate and adaptive immunity by opsonisation of pathogens, recruitment of phagocytes to the site of infection, and direct killing of pathogens through the formation of the membrane-attack complex (Medzhitov, 2007). Here, several complement proteins were also increased in the plasma of cows with endometritis, including complement component-7 (C7) and -9 (C9); complement factor- $\mathrm{H}(\mathrm{CFH}),-\mathrm{D}(\mathrm{CFD})$, and -properdin (CFP); and complement C4-A precursor (C4A13). The presence and activity of serum complement proteins in the bovine uterus during endometritis are not well known. However, physiological hemorrhage from the endometrium and the increased vascular permeability due to mucosal inflammation are likely to facilitate the leakage of cellular and serum components, including complement, to the uterine lumen (Singh et al., 2008).

The protein S100A12 is a member of the S100A calcium-binding proteins that possess inflammatory and innate immune properties against different pathogens (Foell et al., 2013; Zackular et al., 2015). Antimicrobial peptides (AMP), including defensins, have innate and adaptive immune properties and are secreted at the mucosal surface of the female reproductive tract (Hickey et al., 2011; Oppenheim et al., 2003). We observed increased protein levels of S100A12 and $\beta$-defensin in the endometrial tissue during endometritis, which reflects previous marked expression of $S 100$ genes and several AMP genes in cows with severe endometrial inflammation (Wathes et al., 2009). We also observed increased levels of lactoferrin protein, which is known to have important roles in chemotaxis, activation of immune cells, antigen processing, and adaptive immune response (Puddu et al., 2009).

Acute phase proteins (APP) are blood proteins primarily synthesized by hepatocytes as part of the acute phase response, which is in turn part of the earlydefense or innate immune response to different stimuli including infection and inflammation (Cray et al., 2009). Here, we observed increased levels of the APP, SAA, and haptoglobin (HP) in the tissues with endometritis (Supplemental Table S1). Interestingly, these proteins were not significantly elevated in the plasma of the same cows with endometritis. Moreover, SAA-1, SAA-4, and C-reactive protein showed a tendency for decreased levels in the plasma of these cows. Previously, the plasma concentrations of the APP, a1-acid glycoprotein, ceruloplasmin, and HP, were increased in postpartum cows with uterine bacterial contamination, but these proteins returned to basal levels within 14 to $21 \mathrm{~d}$ of uterine involution (Sheldon et al., 2001). Although the plasma concentrations of HP and SAA were higher in cows with postpartum metritis (Huzzey et al., 2009; Chan et al., 2010), the levels of these proteins in prolonged uterine disease (subclinical or clinical endometritis) are largely unknown. The gene transcripts for APP (HP and SAA3) were increased in the endome- 
trium or endometrial cells in response to bacterial presence or inflammation (Gabler et al., 2010; Chapwanya et al., 2012) but not in cows with subclinical or clinical endometritis (Fischer et al., 2010). However, it is not clear whether APP are derived entirely from the liver, or if the endometrial cells can secrete significant levels of these proteins locally in response to infection or inflammation; our findings suggest the latter. However, endometrial cells infected with $E$. coli or exposed to bacterial LPS increased their gene expression of $H P$ and SAA3 (Chapwanya et al., 2013; Oguejiofor et al., 2015b), but the secreted protein concentrations of HP and SAA were not altered (Davies et al., 2008).

Furthermore, we did not observe marked changes in the concentrations of inflammatory cytokines in either the endometrial tissue or the plasma from cows with endometritis. The expression of these cytokines differs depending on the time postpartum and the health condition of the uterus, but their roles in the development of endometritis is not clear. Several previous studies associated the differences in endometrial mRNA expression of inflammatory cytokine genes (e.g., IL1, $I L 6, I L 8$, and $T N F$ ) with the development of clinical or subclinical endometritis (Gabler et al., 2009; Fischer et al., 2010; Kasimanickam et al., 2014). The protein concentration of inflammatory cytokines in the endometrial tissue during endometritis is not known. Their concentrations in uterine flush were observed to differ in cows with clinical or subclinical endometritis (Kim et al., 2014). Moreover, the serum concentrations of

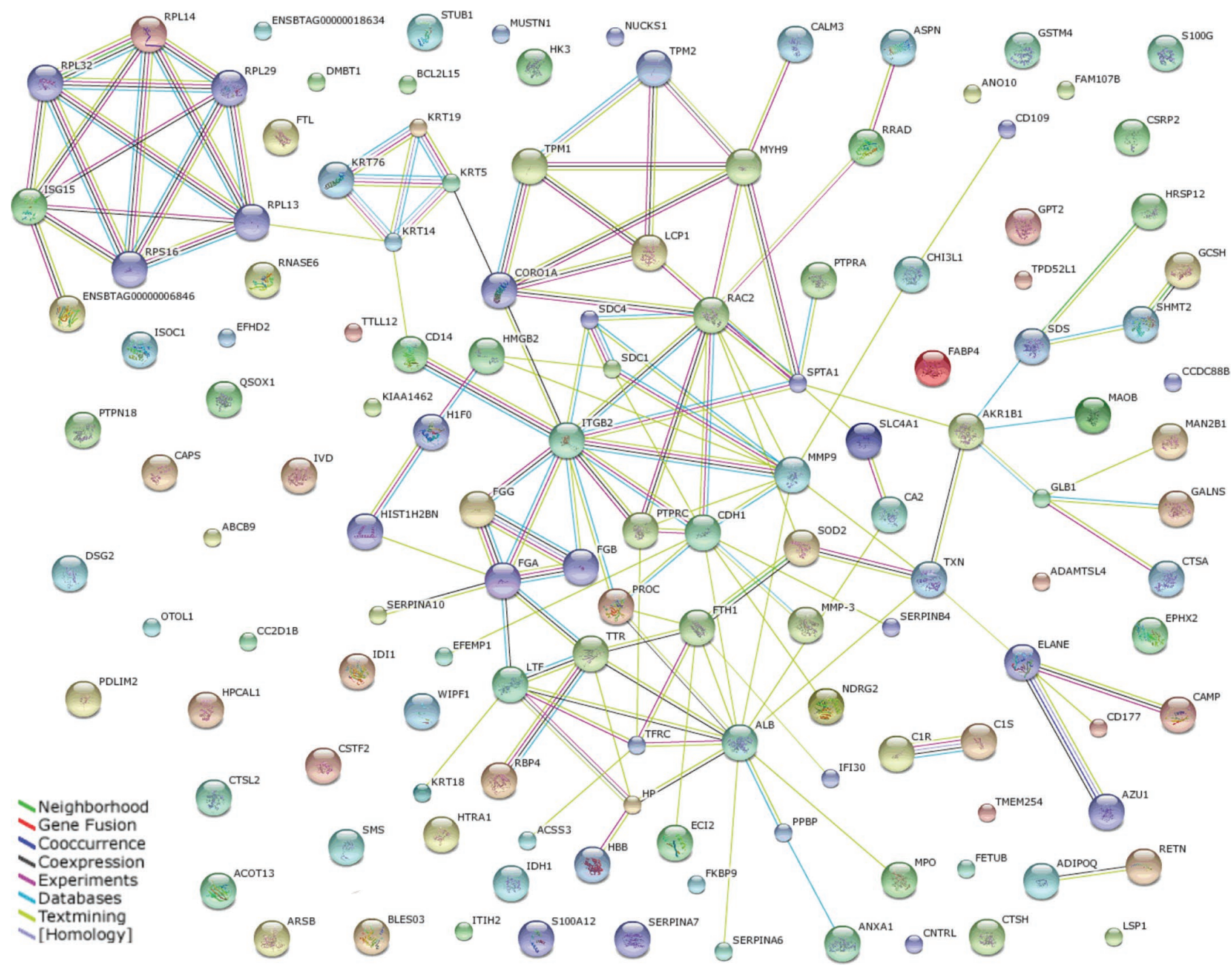

Figure 6. The protein-protein interaction network of differentially expressed proteins from endometrial tissue following analysis by STRING software (https://string-db.org/). An edge was drawn with 8 color lines as shown (see legend), which represent the existence of the 8 types of evidence used in predicting the associations. Color version available online. 
proinflammatory cytokines were increased in the cows with clinical and subclinical endometritis in one study (Kasimanickam et al., 2013), but another study showed no differences (Kim et al., 2014).

The results of GO enrichment analysis of endometrial DEP showed that the most predominant proteins were proteolytic enzymes distributed at the extracellular region, which were activated to respond to stress and stimulus during endometritis (Figure 2). Matrix metalloproteinases (MMP) are a family of mainly extracellular zinc-dependent endoproteinases whose prominent functions include the proteolytic degradation of the extracellular matrix (ECM) proteins and tissue membranes as well as the remodeling of biologically active proteins during morphogenesis, tissue development, wound healing, and reproduction (Page-McCaw et al., 2007; Klein and Bischoff, 2011). Matrix metalloproteinases also regulate inflammation and innate immunity by modulating cytokine and chemokine activity by recruiting leucocytes to the site of inflammation (Parks et al., 2004; Van Lint and Libert, 2007). Uterine infection may alter the levels of MMP and therefore interfere with the mechanism of endometrial repair in the postpartum uterus. Bovine endometrial cells respond to bacterial LPS with increased gene expression of MMP1, MMP3, and MMP13 (Oguejiofor et al., 2015b). The increased endometrial expression of these MMPs, in addition to $M M P$ 9, was also associated with delayed uterine remodeling in postpartum cows (Wathes et al., 2011). We observed significant increases in both MMP3 and MMP9 proteins in the endometrial tissue during endometritis (Figure 5, Supplemental Table S1; https://doi.org/10.3168/jds.2016-12365). Matrix metalloproteinase-9 is a gelatinase that can digest several other ECM molecules, while MMP3 is a stromelysin that can also activate other MMP (Nagase et al., 2006). We hold that increased MMP promoted inflammation and played a role in the ECM degradation and cell or basement membrane damage in endometrial tissue during endometritis (Figure 1B). An imbalance in the proteolytic and antiproteolytic activity of MMP is known to be able to lead to several conditions ranging from tissue destruction in chronic inflammation to cancer metastasis (Klein and Bischoff, 2011). Although ECM remodeling is critical to endometrial receptivity for the embryo (Bauersachs et al., 2006), escalated MMP proteolytic activities are likely to cause chronic inflammation and a hostile uterine environment for reproduction.

In addition to MMP, many other proteins are also known to have extracellular proteolytic activities. Moreover, proteins rarely carry out their functions alone, but often by physically interacting with other proteins (Spirin and Mirny, 2003). In this study, PPI was analyzed using STRING to reveal functional links among the endometrial tissue proteins that were significantly altered in endometritis (Figure 6). The PPI data are commonly shown as networks, which include a node (a protein) and an edge (interaction between proteins). The PPI data are used extensively to assign or predict protein function (Xiong et al., 2013; Yu et al., 2015) and to provide more insight into molecular mechanisms of biological processes (Huang et al., 2015). According to the neighborhood counting approach of protein function prediction, interacting proteins may have some similar functions (Chua et al., 2006; Ng et al., 2010). Our results identified significant enzymatic hydrolase activity in the extracellular region as a possible molecular mechanism through which the DEP may promote inflammation and endometritis. Therefore, some core seed proteins such as RAC2, ITGB2, and CDH1 in the same network with CD14, MMP3, and MMP9 may be related to extracellular hydrolase activity and proteolysis (Figure 6). The definite roles of the identified core seed proteins RAC2, ITGB2, and CDH1 in this hydrolase activity are not clear, but they have critical roles in cell signaling, migration, and adhesion (Ridley, 2006; Sarantos et al., 2008; West and Harris, 2016). Their interactions with CD14, a co-receptor involved in bacterial recognition and innate immune response (Kumar et al., 2011), and MMP highlights the complex network of recognition molecules, adhesion molecules, proteolytic factors, and immune cell migration in the inflammatory process and endometritis. Essentially, the functional roles of adhesion molecules in cell proliferation (George and Dwivedi, 2004) and leucocyte migration (Madri and Graesser, 2000) are facilitated by the cleavage and proteinase activity of MMPs. Therefore, the protein network complemented GO annotation and provided some detailed information about the interactions of DEP in endometritis. Some of these important seed proteins were determined by Western blot, which validated the fold changes from iTRAQ analysis in endometrial tissue (Figure 5).

Additionally, DEP in the plasma were mainly components of the cytosol and non-membrane-bound organelles involved in response to stress and regulation of enzyme activity (Figure 3). A recent study showed that the bovine uterine proteome is dynamic, with the concentrations of proteins including enzymes, antioxidants, and immune molecules in the uterine fluid differing from those of plasma (Faulkner et al., 2012). Interestingly, 9 DEP (Figure 4) overlapped in the endometrial tissue and plasma. Endometrial proteome may have included some blood-derived proteins. Thus, some increased proteins, such as HBB, SAA, and RETN, may have been transferred from blood to the uterus (Figure 4). However, many plasma proteins also differed sig- 
nificantly from the endometrium (Supplemental Table S2, Figure 4). Although plasma and endometrial tissue came from the same cows, the blood cell damage was not confirmed to arise from the inflammatory lesion of the endometrial tissue. The predominant DEP in endometrial tissue were extracellular (Figure 2), whereas the main plasma DEP were intracellular (Figure 3). This pattern indicated that cell damage may have also taken place in the peripheral vessels instead of the uterine endometrium, which is actively regulated by local factors. After all, the blood system is sensitive to any other disease or dysfunction. Therefore, endometrial proteome profiling is thought to be more significant in understanding the endometritis mechanism as well as contributing to the exploration of disease treatment.

\section{CONCLUSIONS}

We used iTRAQ proteomic analysis to determine protein alterations in endometrial tissue and plasma of Chinese Holstein dairy cows with endometritis. The analysis identified 159 and 137 DEP in endometrial tissue and plasma, respectively. Profiling of the endometrial DEP demonstrated that the host defense was activated to protect the endometrium from infection and inflammation. However, bioinformatics analysis of DEP indicated that extracellular hydrolase activity was significantly increased in uterine tissue. Therefore, we propose that inflammatory damage induced by hydrolysis may contribute significantly to the aggravation of endometritis. These findings can facilitate further studies to better understand the molecular mechanisms through which altered proteins may promote inflammation and hence endometritis.

\section{ACKNOWLEDGMENTS}

This work was supported by the Increased Fund of Project Budget of Chinese Academic of Agricultural Science (2014ZL012), the Fund of Innovative Project in Science and Technology of CAAS (CAAS-ASTIP2014-LIHPS-03), the National Key Science and Technology Support Project in the 12th Five-year Plan of China (2012BADB12B03), and the Central Scientific Research Institutes for Basic Research Fund of China (1610322014001). The authors declare no conflict of interest.

\section{REFERENCES}

Azawi, O. I. 2008. Postpartum uterine infection in cattle. Anim. Reprod. Sci. 105:187-208.

Barlund, C. S., T. D. Carruthers, C. L. Waldner, and C. W. Palmer. 2008. A comparison of diagnostic techniques for postpartum endometritis in dairy cattle. Theriogenology 69:714-723.
Bauersachs, S., S. E. Ulbrich, K. Gross, S. E. Schmidt, H. H. Meyer, H. Wenigerkind, M. Vermehren, F. Sinowatz, H. Blum, and E. Wolf. 2006. Embryo-induced transcriptome changes in bovine endometrium reveal species-specific and common molecular markers of uterine receptivity. Reproduction 132:319-331.

Berendt, F. J., T. Frohlich, S. E. Schmidt, H. D. Reichenbach, E. Wolf, and G. J. Arnold. 2005. Holistic differential analysis of embryoinduced alterations in the proteome of bovine endometrium in the preattachment period. Proteomics 5:2551-2560.

Bicalho, M. L. S., V. S. Machado, G. Oikonomou, R. O. Gilbert, and R. C. Bicalho. 2012. Association between virulence factors of Escherichia coli, Fusobacterium necrophorum, and Arcanobacterium pyogenes and uterine diseases of dairy cows. Vet. Microbiol. 157:125-131.

Bondurant, R. H. 1999. Inflammation in the bovine female reproductive tract. J. Anim. Sci. 77(Suppl. 2):101-110.

Braff, M. H., A. Bardan, V. Nizet, and R. L. Gallo. 2005. Cutaneous defense mechanisms by antimicrobial peptides. J. Invest. Dermatol. 125:9-13.

Chan, J. P., C. C. Chang, W. L. Hsu, W. B. Liu, and T. H. Chen. 2010. Association of increased serum acute-phase protein concentrations with reproductive performance in dairy cows with postpartum metritis. Vet. Clin. Pathol. 39:72-78.

Chapwanya, A., K. G. Meade, M. L. Doherty, J. J. Callanan, and C. O'Farrelly. 2013. Endometrial epithelial cells are potent producers of tracheal antimicrobial peptide and serum amyloid A3 gene expression in response to E. coli stimulation. Vet. Immunol. Immunopathol. 151:157-162.

Chapwanya, A., K. G. Meade, C. Foley, F. Narciandi, A. C. Evans, M. L. Doherty, J. J. Callanan, and C. O'farrelly. 2012. The postpartum endometrial inflammatory response: A normal physiological event with potential implications for bovine fertility. Reprod. Fertil. Dev. 24:1028-1039.

Cheng, Z., A. Abudureyimu, C. F. Oguejiofor, R. Ellis, A. T. Barry, X. Chen, O. L. Anstaett, J. Brownlie, and D. C. Wathes. 2016. BVDV alters uterine prostaglandin production during pregnancy recognition in cows. Reproduction 151:605-614.

Choe, C., J. W. Park, E. S. Kim, S. G. Lee, S. Y. Park, J. S. Lee, M. J. Cho, K. R. Kang, J. Han, and D. Kang. 2010. Proteomic analysis of differentially expressed proteins in bovine endometrium with endometritis. Korean J. Physiol. Pharmacol. 14:205-212.

Chua, H. N., W. K. Sung, and L. Wong. 2006. Exploiting indirect neighbours and topological weight to predict protein function from protein-protein interactions. Bioinformatics 22:1623-1630.

Cray, C., J. Zaias, and N. H. Altman. 2009. Acute phase response in animals: A review. Comp. Med. 59:517-526.

Davies, D., K. G. Meade, S. Herath, P. D. Eckersall, D. Gonzalez, J. O. White, R. S. Conlan, C. O'farrelly, and I. M. Sheldon. 2008. Tolllike receptor and antimicrobial peptide expression in the bovine endometrium. Reprod. Biol. Endocrinol. 6:53.

Dohmen, M. J., K. Joop, A. Sturk, P. E. Bols, and J. A. Lohuis. 2000. Relationship between intra-uterine bacterial contamination, endotoxin levels and the development of endometritis in postpartum cows with dystocia or retained placenta. Theriogenology 54:1019 1032.

Dohmen, M. J. W., J. A. C. M. Lohuis, G. Huszenicza, P. Nagy, and M. Gacs. 1995. The relationship between bacteriological and clinical findings in cows with subacute/chronic endometritis. Theriogenology 43:1379-1388.

Donofrio, G., V. Franceschi, A. Capocefalo, S. Cavirani, and I. M. Sheldon. 2009. Isolation and characterization of bovine herpesvirus 4 (BoHv-4) from a cow affected by postpartum metritis and cloning of the genome as a bacterial artificial chromosome. Reprod. Biol. Endocrinol. 7:83.

Faulkner, S., G. Elia, M. P. Mullen, P. O'Boyle, M. J. Dunn, and D. Morris. 2012. A comparison of the bovine uterine and plasma proteome using iTRAQ proteomics. Proteomics 12:2014-2023.

Fischer, C., M. Drillich, S. Odau, W. Heuwieser, R. Einspanier, and C. Gabler. 2010. Selected pro-inflammatory factor transcripts in bovine endometrial epithelial cells are regulated during the oestrous 
cycle and elevated in case of subclinical or clinical endometritis. Reprod. Fertil. Dev. 22:818-829.

Foell, D., H. Wittkowski, C. Kessel, A. Luken, T. Weinhage, G. Varga, T. Vogl, T. Wirth, D. Viemann, P. Bjork, M. A. Van Zoelen, F. Gohar, G. Srikrishna, M. Kraft, and J. Roth. 2013. Proinflammatory S100A12 can activate human monocytes via Toll-like receptor 4. Am. J. Respir. Crit. Care Med. 187:1324-1334.

Foley, C., A. Chapwanya, C. J. Creevey, F. Narciandi, D. Morris, E. M. Kenny, P. Cormican, J. J. Callanan, C. O'farrelly, and K. G. Meade. 2012. Global endometrial transcriptomic profiling: Transient immune activation precedes tissue proliferation and repair in healthy beef cows. BMC Genomics 13:489.

Gabler, C., M. Drillich, C. Fischer, C. Holder, W. Heuwieser, and R. Einspanier. 2009. Endometrial expression of selected transcripts involved in prostaglandin synthesis in cows with endometritis. Theriogenology 71:993-1004.

Gabler, C., C. Fischer, M. Drillich, R. Einspanier, and W. Heuwieser. 2010. Time-dependent mRNA expression of selected pro-inflammatory factors in the endometrium of primiparous cows postpartum. Reprod. Biol. Endocrinol. 8:152.

Galvão, K. N., N. R. Santos, J. S. Galvão, and R. O. Gilbert. 2011. Association between endometritis and endometrial cytokine expression in postpartum Holstein cows. Theriogenology 76:290-299.

George, S. J., and A. Dwivedi. 2004. MMPs, cadherins, and cell proliferation. Trends Cardiovasc. Med. 14:100-105.

Gilbert, R. O. 2011. The effects of endometritis on the establishment of pregnancy in cattle. Reprod. Fertil. Dev. 24:252-257.

Gilbert, R. O., S. T. Shin, C. L. Guard, H. N. Erb, and M. Frajblat. 2005. Prevalence of endometritis and its effects on reproductive performance of dairy cows. Theriogenology 64:1879-1888.

Grooms, D. L. 2004. Reproductive consequences of infection with bovine viral diarrhea virus. Vet. Clin. North Am. Food Anim. Pract. 20:5-19.

Hickey, D. K., M. V. Patel, J. V. Fahey, and C. R. Wira. 2011. Innate and adaptive immunity at mucosal surfaces of the female reproductive tract: Stratification and integration of immune protection against the transmission of sexually transmitted infections. J. Reprod. Immunol. 88:185-194.

Huang, Y. A., Z. H. You, X. Gao, L. Wong, and L. Wang. 2015. Using weighted sparse representation model combined with discrete cosine transformation to predict protein-protein interactions from protein sequence. BioMed Res. Int. 2015:902198.

Huzzey, J. M., T. F. Duffield, S. J. Leblanc, D. M. Veira, D. M. Weary, and M. A. Von Keyserlingk. 2009. Short communication: Haptoglobin as an early indicator of metritis. J. Dairy Sci. 92:621-625.

Islam, R., H. Kumar, S. Nandi, and R. B. Rai. 2013. Determination of anti-inflammatory cytokine in periparturient cows for prediction of postpartum reproductive diseases. Theriogenology 79:974-979.

Jabbour, H. N., K. J. Sales, R. D. Catalano, and J. E. Norman. 2009. Inflammatory pathways in female reproductive health and disease. Reproduction 138:903-919.

Kasimanickam, R., T. F. Duffield, R. A. Foster, C. J. Gartley, K. E Leslie, J. S. Walton, and W. H. Johnson. 2004. Endometrial cytology and ultrasonography for the detection of subclinical endometritis in postpartum dairy cows. Theriogenology 62:9-23.

Kasimanickam, R., V. Kasimanickam, and J. P. Kastelic. 2014. Mucin 1 and cytokines mRNA in endometrium of dairy cows with postpartum uterine disease or repeat breeding. Theriogenology 81:952-958.

Kasimanickam, R. K., V. R. Kasimanickam, J. R. Olsen, E. J. Jeffress, D. A. Moore, and J. P. Kastelic. 2013. Associations among serum pro- and anti-inflammatory cytokines, metabolic mediators, body condition, and uterine disease in postpartum dairy cows. Reprod. Biol. Endocrinol. 11:103

Kim, I. H., H. G. Kang, J. K. Jeong, T. Y. Hur, and Y. H. Jung. 2014 Inflammatory cytokine concentrations in uterine flush and serum samples from dairy cows with clinical or subclinical endometritis. Theriogenology 82:427-432.

Klein, T., and R. Bischoff. 2011. Physiology and pathophysiology of matrix metalloproteases. Amino Acids 41:271-290.
Kumar, H., T. Kawai, and S. Akira. 2011. Pathogen recognition by the innate immune system. Int. Rev. Immunol. 30:16-34.

LeBlanc, S. J. 2014. Reproductive tract inflammatory disease in postpartum dairy cows. Animal 8(Suppl. 1):54-63.

LeBlanc, S. J., T. Osawa, and J. Dubuc. 2011. Reproductive tract defense and disease in postpartum dairy cows. Theriogenology $76: 1610-1618$.

Ledgard, A. M., R. S. Lee, and A. J. Peterson. 2009. Bovine endometrial legumain and TIMP-2 regulation in response to presence of a conceptus. Mol. Reprod. Dev. 76:65-74.

Madri, J. A., and D. Graesser. 2000. Cell migration in the immune system: The evolving inter-related roles of adhesion molecules and proteinases. Dev. Immunol. 7:103-116.

Maybin, J. A., H. O. Critchley, and H. N. Jabbour. 2011. Inflammatory pathways in endometrial disorders. Mol. Cell. Endocrinol. 335:42-51.

Medzhitov, R. 2007. Recognition of microorganisms and activation of the immune response. Nature 449:819-826.

Nagase, H., R. Visse, and G. Murphy. 2006. Structure and function of matrix metalloproteinases and TIMPs. Cardiovasc. Res. 69:562573.

Ng, K. L., J. S. Ciou, and C. H. Huang. 2010. Prediction of protein functions based on function-function correlation relations. Comput. Biol. Med. 40:300-305.

Oguejiofor, C. F., Z. Cheng, A. Abudureyimu, O. L. Anstaett, J Brownlie, A. A. Fouladi-Nashta, and D. C. Wathes. 2015a. Global transcriptomic profiling of bovine endometrial immune response in vitro. II. Effect of bovine viral diarrhea virus on the endometrial response to lipopolysaccharide. Biol. Reprod. 93:101.

Oguejiofor, C. F., Z. Cheng, A. Abudureyimu, A. A. Fouladi-Nashta, and D. C. Wathes. 2015b. Global transcriptomic profiling of bovine endometrial immune response in vitro. I. Effect of lipopolysaccharide on innate immunity. Biol. Reprod. 93:100.

Oppenheim, J. J., A. Biragyn, L. W. Kwak, and D. Yang. 2003. Roles of antimicrobial peptides such as defensins in innate and adaptive immunity. Ann. Rheum. Dis. 62(Suppl. 2):ii17-ii21.

Page-McCaw, A., A. J. Ewald, and Z. Werb. 2007. Matrix metalloproteinases and the regulation of tissue remodelling. Nat. Rev. Mol. Cell Biol. 8:221-233.

Parks, W. C., C. L. Wilson, and Y. S. Lopez-Boado. 2004. Matrix metalloproteinases as modulators of inflammation and innate immunity. Nat. Rev. Immunol. 4:617-629.

Plöntzke, J., L. V. Madoz, R. L. De La Sota, M. Drillich, and W. Heuwieser. 2010. Subclinical endometritis and its impact on reproductive performance in grazing dairy cattle in Argentina. Anim. Reprod. Sci. 122:52-57.

Puddu, P., P. Valenti, and S. Gessani. 2009. Immunomodulatory effects of lactoferrin on antigen presenting cells. Biochimie 91:11-18.

Ridley, A. J. 2006. Rho GTPases and actin dynamics in membrane protrusions and vesicle trafficking. Trends Cell Biol. 16:522-529.

Sarantos, M. R., H. Zhang, U. Y. Schaff, N. Dixit, H. N. Hayenga, C. A. Lowell, and S. I. Simon. 2008. Transmigration of neutrophils across inflamed endothelium is signaled through LFA-1 and Src family kinase. J. Immunol. 181:8660-8669.

Sheldon, I. M., J. Cronin, L. Goetze, G. Donofrio, and H. J. Schuberth. 2009a. Defining postpartum uterine disease and the mechanisms of infection and immunity in the female reproductive tract in cattle. Biol. Reprod. 81:1025-1032.

Sheldon, I. M., and H. Dobson. 2004. Postpartum uterine health in cattle. Anim. Reprod. Sci. 82-83:295-306.

Sheldon, I. M., G. S. Lewis, S. Leblanc, and R. O. Gilbert. 2006 Defining postpartum uterine disease in cattle. Theriogenology 65:1516-1530.

Sheldon, I. M., D. E. Noakes, A. Rycroft, and H. Dobson. 2001. Acute phase protein responses to uterine bacterial contamination in cattle after calving. Vet. Rec. 148:172-175.

Sheldon, I. M., S. B. Price, J. Cronin, R. O. Gilbert, and J. E. Gadsby. 2009b. Mechanisms of infertility associated with clinical and subclinical endometritis in high producing dairy cattle. Reprod. Domest. Anim. 44(Suppl. 3):1-9. 
Sheldon, I. M., E. J. Williams, A. N. Miller, D. M. Nash, and S. Herath. 2008. Uterine diseases in cattle after parturition. Vet. J. $176: 115-121$

Singh, J., R. D. Murray, G. Mshelia, and Z. Woldehiwet. 2008. The immune status of the bovine uterus during the peripartum period. Vet. J. 175:301-309.

Spirin, V., and L. A. Mirny. 2003. Protein complexes and functional modules in molecular networks. Proc. Natl. Acad. Sci. USA 100:12123-12128.

Van Lint, P., and C. Libert. 2007. Chemokine and cytokine processing by matrix metalloproteinases and its effect on leukocyte migration and inflammation. J. Leukoc. Biol. 82:1375-1381.

Wathes, D. C., Z. Cheng, W. Chowdhury, M. A. Fenwick, R. Fitzpatrick, D. G. Morris, J. Patton, and J. J. Murphy. 2009. Negative energy balance alters global gene expression and immune responses in the uterus of postpartum dairy cows. Physiol. Genomics 39:1-13.

Wathes, D. C., Z. Cheng, M. A. Fenwick, R. Fitzpatrick, and J. Patton. 2011. Influence of energy balance on the somatotrophic axis and matrix metalloproteinase expression in the endometrium of the postpartum dairy cow. Reproduction 141:269-281.
West, J. J., and T. J. C. Harris. 2016. Cadherin trafficking for tissue morphogenesis: Control and consequences. Traffic 17:1233-1243.

Westermann, S., M. Drillich, T. B. Kaufmann, L. V. Madoz, and W. Heuwieser. 2010. A clinical approach to determine false positive findings of clinical endometritis by vaginoscopy by the use of uterine bacteriology and cytology in dairy cows. Theriogenology 74:1248-1255.

Williams, E. J., D. P. Fischer, D. U. Pfeiffer, G. C. England, D. E. Noakes, H. Dobson, and I. M. Sheldon. 2005. Clinical evaluation of postpartum vaginal mucus reflects uterine bacterial infection and the immune response in cattle. Theriogenology 63:102-117.

Xiong, W., H. Liu, J. Guan, and S. Zhou. 2013. Protein function prediction by collective classification with explicit and implicit edges in protein-protein interaction networks. BMC Bioinformatics 14(Suppl. 12):S4.

Yu, G., H. Zhu, C. Domeniconi, and M. Guo. 2015. Integrating multiple networks for protein function prediction. BMC Syst. Biol. 9(Suppl. 1):S3.

Zackular, J. P., W. J. Chazin, and E. P. Skaar. 2015. Nutritional immunity: S100 proteins at the host-pathogen interface. J. Biol. Chem. 290:18991-18998. 